\title{
Evaluating management-induced soil salinization in golf courses in semi-arid landscapes
}

\author{
J. Young ${ }^{1}$, T. K. Udeigwe ${ }^{1}$, D. C. Weindorf ${ }^{1}$, T. Kandakji ${ }^{1}$, P. Gautam ${ }^{1}$, and M. A. Mahmoud ${ }^{2}$ \\ ${ }^{1}$ Department of Plant and Soil Science, Texas Tech University, Lubbock, Texas, TX 79409, USA \\ ${ }^{2}$ Soil, Water and Environment Research Institute (SWERI), Agricultural Research Center (ARC), Giza, Egypt \\ Correspondence to: T. K. Udeigwe (theo.udeigwe@ttu.edu)
}

Received: 2 November 2014 - Published in Solid Earth Discuss.: 13 January 2015

Revised: 14 March 2015 - Accepted: 18 March 2015 - Published: 13 April 2015

\begin{abstract}
Site-specific information on land management practices are often desired to make better assessments of their environmental impacts. A study was conducted in Lubbock, Texas, in the Southern High Plains of the United States, an area characterized by semi-arid climatic conditions, to (1) examine the potential management-induced alterations in soil salinity indicators in golf course facilities and (2) develop predictive relationships for a more rapid soil salinity examination within these urban landscape soils using findings from a portable X-ray fluorescence (PXRF) spectrometer. Soil samples were collected from managed (well irrigated) and non-managed (non-irrigated) areas of seven golf course facilities at $0-10,10-20$, and $20-30 \mathrm{~cm}$ depths and analyzed for a suite of chemical properties. Among the extractable cations, sodium (Na) was significantly $(p<0.05)$ higher in the managed zones of all the golf facilities. Soil electrical conductivity (EC), exchangeable sodium percentage (ESP), and sodium adsorption ratio (SAR), parameters often used in characterizing soil salinity and sodicity, were for the most part significantly $(p<0.05)$ higher in the managed areas. Water quality reports collected over a 22 -year period (1991-2013, all years not available) indicated a gradual increase in $\mathrm{pH}, \mathrm{EC}, \mathrm{SAR}$, total alkalinity, and extractable ions, thus supporting the former findings. Findings from the PXRF suggested possible differences in chemical species and sources that contribute to salinity between the managed and non-managed zones. PXRF-quantified $\mathrm{Cl}$ and $\mathrm{S}$, and to a lesser extent $\mathrm{Ca}$, individually and collectively explained 23 $85 \%$ of the variability associated with soil salinity at these facilities.
\end{abstract}

\section{Introduction}

Soil salinization is a global environmental problem that has gained a lot of research attention over the years (Pitman and Läuchli, 2002; Martinez-Beltran and Manzur, 2005; Herrero and Pérez-Coveta, 2005; Fan et al., 2012). Site-specific research on soil salinization is often needed because generalization of findings could be misleading. The Southern High Plains (SHP) of the USA, an area characterized by semi-arid climatic conditions (Peel et al., 2007), is noted for complex environmental challenges such as drought, dust, wind erosion, soil salinization, and nutrient deficiency. Nevertheless, in this region lie very important economic cities, such as Lubbock, that substantially contribute to US cotton production (USDA-NASS, 2014). Lubbock, located in the northwestern part of Texas, among other environmental challenges is currently plagued by extreme water scarcity attributed to low precipitation (a 30-year average annual precipitation of approximately $470 \mathrm{~mm}$ ) and the declining local aquifer, the Ogallala. Recent observations have also shown an increasing pollutant concentration in well waters (Scanlon et al., 2005); therefore, the water quality of the aquifer has also become an issue of concern. Thus, the intensification of agricultural and municipal activities could have a substantial impact on water quantity and soil quality in this region.

In most semi-arid and arid regions of the world, the unavailability of sufficient rainfall is often associated with impaired soil quality as salts tend to accumulate in the soil as a result of limited leaching (Pariente, 2001). This could result in soil salinization, a process in which salts build up in the soil to a potentially toxic level (Pitman and Läuchli, 2002; Rengasamy, 2006). Such altered chemical properties 
could affect the soil's hydraulic properties, susceptibility to erosion (Morgan, 2009), environmental fate of soil pollutants (Du et al., 2009), and nutrient availability to agronomic crops (Havlin et al., 2005). Poor-quality irrigation water could also worsen such scenarios as more contaminants from the water are continuously added; a typical case is the declining Ogallala Aquifer, which has been noted as a potential source of arsenic (As) and nitrate $\left(\mathrm{NO}_{3}^{-}\right)$to irrigated agricultural soils in the SHP (Hudak, 2000; Scanlon et al., 2005). Although a common topic, there are still very limited scientific reference materials on soil salinization in agricultural and urban landscapes in the study area.

The first approach to addressing environmental degradations resulting from contaminations is usually the identification of the major contributors. Evidently, in this region, management (irrigation)-induced soil salinization has received less attention, particularly within urban landscape facilities such as golf courses, despite its severity. Golf courses are major users of irrigation water per unit area; a typical 18hole golf facility in the southwest region could use an average of approximately $1200 \mathrm{~mm} \mathrm{yr}^{-1}$ of water (USGA, 2012) compared to $600 \mathrm{~mm} \mathrm{yr}^{-1}$ for a fully irrigated cotton field in the same region (Snowden et al., 2013). Thus, in assessing the potential impact of impaired water quality on soil and other environmental media in any setting, it is logical to examine the contributions of major irrigation water users in that given region of interest. With the increasing severity of environmental degradation in the SHP region, it is of great interest to attempt to extend the applications of modern tools such as the portable X-ray fluorescence (PXRF) for a more rapid investigation of environmental contamination, particularly relating to soil salinization in golf course facilities. This tool is gaining importance in the fields of soil and environmental sciences (Kilbride et al., 2006; Jang, 2010; McWhirt et al., 2012; Gardner et al., 2013; Hu et al., 2014; Weindorf et al., 2014). Swanhart et al. (2015) demonstrated the utility of applying PXRF to soil salinity determination. This approach was further refined by Aldabaa et al. (2015), who coupled PXRF data with visible near-infrared diffuse reflectance spectra as well as hyperspectral satellite data for improved measurement of salinity in playas of western Texas, USA. This tool has also been extended to gypsum determination in arid soils (Weindorf et al., 2013). This study serves as an attempt to extend the application of the PXRF to soil salinity examination in urban landscapes of the semi-arid climates. The main advantage of this tool is its ability to quantify elements in an environmental medium such as soil with minimal need for sample preparation, thereby saving time and labor (Kalnicky and Singhvi, 2001) compared to the traditional wet chemistry techniques. Likewise, other tools for field-scale salinity measurement, such as electromagnetic induction, will not provide information on the chemical species contributing or controlling salinity.

We hypothesize that there will be significant differences in key chemical properties between managed and non-managed areas of golf course facilities. This was deduced from the fact that in addition to the unique management practices of golf course facilities such as perennial monoculture, less soil pulverization, and extended irrigation window, the managed zones are frequently irrigated and would reflect the state of the irrigation water quality. Given the semi-arid climatic condition of the study area and the characteristically alkaline nature of the soils, these hypothesized differences could be more obvious in their salinity and/or sodicity properties. Thus, the objectives of this study were to (1) examine the possible management-induced changes in soil chemical properties, particularly those significant to salinization, within golf course facilities in a semi-arid climate, and (2) develop predictive relationships for a more rapid soil salinity examination within these urban landscape soils using findings from a PXRF spectrometer.

\section{Materials and methods}

\subsection{Study site description}

This study was conducted in Lubbock, Texas, USA. Lubbock lies within $33^{\circ} 34^{\prime} \mathrm{N}$ and $101^{\circ} 53^{\prime} \mathrm{W}$ and sits on an elevation of $990 \mathrm{~m}$ above sea level (USGS, 2014). This area is characterized by semi-arid climatic conditions. Mean weather parameters recorded in 2013 when soil sampling was conducted were $320 \mathrm{~mm}$ (for precipitation), $16.1{ }^{\circ} \mathrm{C}$ (ambient air temperature), $53 \%$ (relative humidity), and $29.3 \mathrm{kph}$ (wind speed) (NOAA, 2015). Geological materials are composed mainly of Quaternary aeolian sand and loess (Nordstrom and Hotta, 2004). To achieve our objectives, seven golf course facilities spread all over the city were selected for this study. Each facility has been under management for at least 12 years. Figure 1 shows the locations of the selected facilities, which are designated as A, B, C, D, E, F, and G. Using web soil survey, soil types at the sites were broadly identified to belong to the Amarillo (fine-loamy, mixed, superactive, thermic Aridic Paleustalfs) and Acuff series (fine-loamy, mixed, superactive, thermic Aridic Paleustolls). The average golf course contains 10 to 12 ha of irrigated fairways. All managed fairways were planted with common bermuda grass (Cynodon dactylon (L.) Pers.) or hybrid bermuda grass (Cynodon dactylon (L.) Pers. $\times$ C. transvaalensis Burtt-Davy) while the non-managed areas were composed of poorly managed grass cover, native vegetation, or bare soil.

\subsection{Soil sampling and handling}

The fairways, which are consistently irrigated, were designated as the "managed areas", whereas adjacent areas of similar soil types that are not irrigated or managed were designated as the "non-managed areas" in each facility. In each managed and non-managed area, three core samples were randomly collected using a $30 \mathrm{~cm}$ long $\times 6 \mathrm{~cm}$ wide (diameter) core sampler and then separated into three depths of $0-10,10-20$, and $20-30 \mathrm{~cm}$; then samples from same depth 


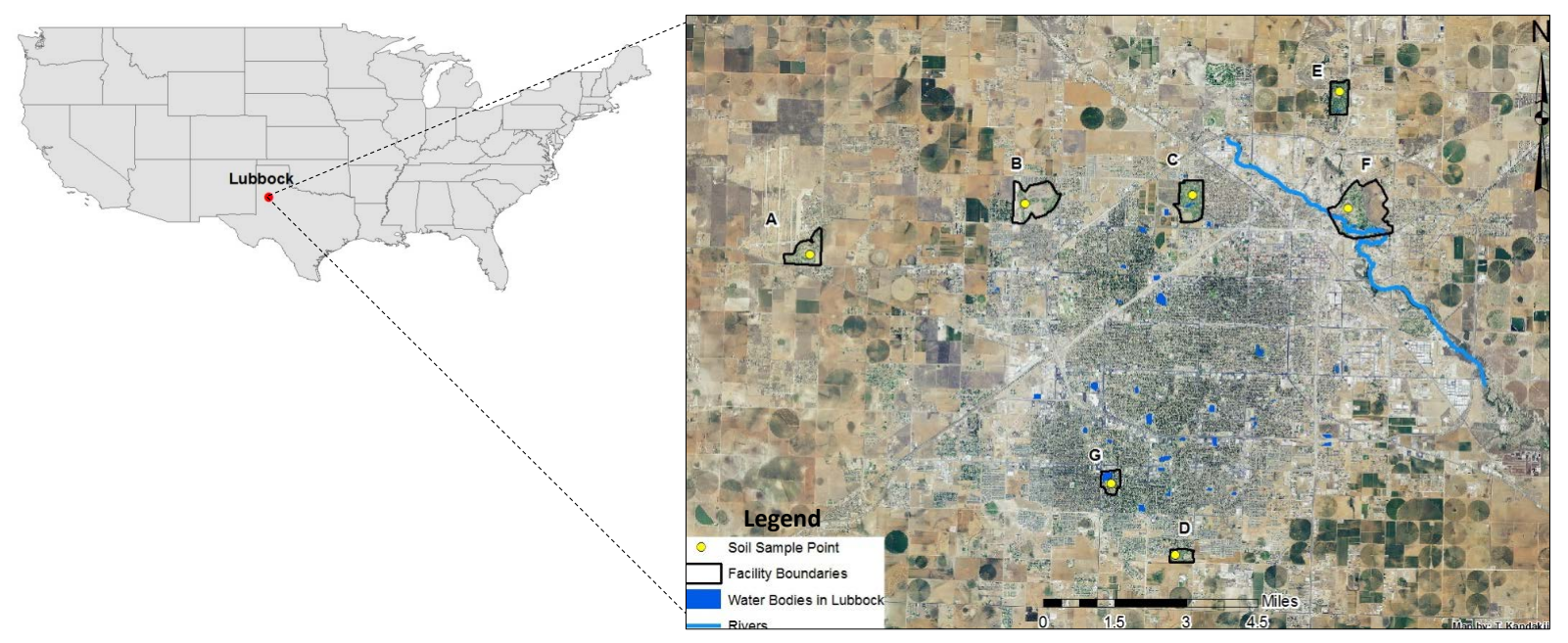

Figure 1. Map showing the study area located in Lubbock, Texas, USA, and the locations of the seven golf facilities. The facilities are designated as A, B, C, D, E, F, and G.

were combined to get a representative sample for each depth. Soil sampling was conducted once during the months of June and July in 2013. Sampling was conducted only once since the aim of the study was to evaluate the resultant cumulative effect of many years (>12 years) of management practices on soil chemical properties of interest. Collected soil samples were then transported to the laboratory, air dried, ground, and passed through a $2 \mathrm{~mm}$ sieve before characterization.

\subsection{Soil characterization}

Soil samples were analyzed for a suite of chemical properties. Soil electrical conductivity (EC) and $\mathrm{pH}$ were measured in a $1: 2$ solid (soil) to water suspension (Rhoades, 1996). Total carbon (TC) and total nitrogen (TN) were analyzed using a TruSpec C/N analyzer (LECO, St Joseph, MI, USA). Organic matter $(\mathrm{OM})$ was determined using a modified Walkley and Black method (Nelson and Sommers, 1996), using sodium (Na) dichromate and read on a Gilford unit. Percent calcium carbonate $\left(\mathrm{CaCO}_{3}\right)$ was determined by the tensimeter approach (Soil Survey Staff, 1996), a modification of the pressure calcimeter approach (Loeppert and Suarez, 1996). Exchangeable $\mathrm{Na}$, calcium (Ca), magnesium ( $\mathrm{Mg})$, and potassium $(\mathrm{K})$ were measured in ammonium acetate extract (Soil Survey Staff, 2009) using atomic absorption spectrometer (Spectra AA 220, Varian, Palo Alto, California). Exchangeable sodium percentage (ESP) was calculated using measured exchangeable cation values (Sparks, 2003). Sodium adsorption ratio (SAR) was determined using the established relationship between ESP and SAR of saturated extract developed by US Salinity Laboratory (Richards, 1954; Sparks, 2003). For the purpose and scope of this study, waterextractable chloride $\left(\mathrm{Cl}^{-}\right)$and bicarbonate $\left(\mathrm{HCO}_{3}^{-}\right)$were measured in 1:5 soil water extract and $\mathrm{Cl}^{-}$concentration determined by titration with $0.005 \mathrm{M}$ silver nitrate $\left(\mathrm{AgNO}_{3}\right)$ standard following the Mohr titration approach (Soil Survey Staff, 1996), and $\mathrm{HCO}_{3}^{-}$by titration with $0.01 \mathrm{M}$ sulfuric acid $\left(\mathrm{H}_{2} \mathrm{SO}_{4}\right)$ (Soil Survey Staff, 1996).

\subsection{PXRF scanning}

Collected samples were scanned using a PXRF (DP-6000 Delta Premium, Olympus, Waltham, MA, USA) equipped with a Rh-X-ray tube which is operated at $10-40 \mathrm{kV}$ with integrated silicon drift detector $(165 \mathrm{eV}$ ) (US Environmental Protection Agency (USEPA), 2007). The tool was operated in the soil mode to measure a suite of elements, among which only $\mathrm{Cl}, \mathrm{K}, \mathrm{S}$, and $\mathrm{Ca}$ were selected for our purpose. Importantly, PXRF is not able to quantify Na given its small, stable electron cloud. Soil mode consists of three beams operating sequentially, each set to scan for $30 \mathrm{~s}$ for a total scan time of $90 \mathrm{~s}$ per sample. Calibration of the instrument was conducted before sample analysis using a 316 alloy chip fitted to the aperture. Each soil sample was scanned in triplicate and the average value reported. The data on elemental concentration and limit of detection ( 3 times the standard error) were obtained and compiled.

\subsection{Water quality}

Water quality reports were obtained from the various golf course facilities, where available. Since the facilities pump from the same groundwater source, the available reports were enough to achieve the objectives of this study. In summary, 12 years (1991-2013, not all years were included) of data were provided by one of the facilities, 2 years by another (2009-2010), and 1 year each (2011 and 2013) by the remaining two facilities. The data sets broken down by water sources were from a well (12 years of data), a retention pond (3 years), and recycled wastewater (1 year). Water quality 
Table 1. Selected soil properties examined at the managed and non-managed areas of the seven golf facilities in Lubbock, Texas, USA $(n=3)$.

\begin{tabular}{|c|c|c|c|c|c|c|c|}
\hline $\begin{array}{l}\text { Golf } \\
\text { course }\end{array}$ & Management & $\begin{array}{l}\text { Irrigation } \\
\text { source }\end{array}$ & $\mathrm{pH}$ & $\mathrm{CaCO}_{3}$ & $\begin{array}{r}\mathrm{TC} \\
\%\end{array}$ & $\mathrm{TN}$ & $\mathrm{OM}$ \\
\hline \multirow[t]{2}{*}{ A } & Managed & Well & $8.2 \mathrm{a}$ & $1.1 \mathrm{a}$ & $1.88 \mathrm{a}$ & $0.19 \mathrm{a}$ & $1.5 \mathrm{a}$ \\
\hline & Non-managed & & $8.1 \mathrm{a}$ & $0.2 b$ & $0.77 \mathrm{a}$ & $0.07 \mathrm{a}$ & $0.7 \mathrm{a}$ \\
\hline \multirow[t]{2}{*}{ B } & Managed & Well & $8.3 b$ & $8.8 \mathrm{a}$ & $2.31 \mathrm{a}$ & $0.14 a$ & $1.0 \mathrm{a}$ \\
\hline & Non-managed & & $8.4 \mathrm{a}$ & $4.5 \mathrm{a}$ & $1.20 \mathrm{~b}$ & $0.07 \mathrm{a}$ & $0.5 \mathrm{a}$ \\
\hline \multirow[t]{2}{*}{$\mathrm{C}$} & Managed & Well & $8.2 b$ & $1.9 \mathrm{a}$ & $1.68 \mathrm{a}$ & $0.13 a$ & $1.2 \mathrm{a}$ \\
\hline & Non-managed & & $8.5 \mathrm{a}$ & $1.2 \mathrm{a}$ & $0.89 a$ & $0.07 \mathrm{a}$ & $0.5 \mathrm{a}$ \\
\hline \multirow[t]{2}{*}{$\mathrm{D}$} & Managed & Well & $8.6 a$ & $0.5 \mathrm{a}$ & $0.87 \mathrm{a}$ & $0.08 \mathrm{a}$ & $0.8 \mathrm{a}$ \\
\hline & Non-managed & & $8.6 a$ & $0.7 \mathrm{a}$ & $0.47 \mathrm{a}$ & $0.03 a$ & $0.3 \mathrm{a}$ \\
\hline \multirow[t]{2}{*}{$\mathrm{E}$} & Managed & Well & $8.2 \mathrm{a}$ & $4.6 \mathrm{a}$ & $2.24 \mathrm{a}$ & $0.18 \mathrm{a}$ & $1.1 \mathrm{a}$ \\
\hline & Non-managed & & 7.9a & $6.4 \mathrm{a}$ & $2.96 \mathrm{a}$ & $0.22 \mathrm{a}$ & $1.3 \mathrm{a}$ \\
\hline \multirow[t]{2}{*}{$\mathrm{F}$} & Managed & Well \& RW & $8.0 \mathrm{a}$ & $0.7 \mathrm{a}$ & $1.91 \mathrm{a}$ & $0.18 \mathrm{a}$ & $1.3 \mathrm{a}$ \\
\hline & Non-managed & & $8.1 \mathrm{~b}$ & $1.6 \mathrm{a}$ & $1.57 \mathrm{a}$ & $0.13 \mathrm{a}$ & $0.9 \mathrm{a}$ \\
\hline \multirow[t]{2}{*}{ G } & Managed & Well \& RP & $8.1 \mathrm{a}$ & $4.2 \mathrm{a}$ & $2.86 a$ & $0.21 \mathrm{a}$ & $1.5 \mathrm{a}$ \\
\hline & Non-managed & & $8.3 \mathrm{a}$ & $4.7 \mathrm{a}$ & $1.48 \mathrm{a}$ & $0.06 \mathrm{a}$ & $0.7 \mathrm{a}$ \\
\hline
\end{tabular}

TC is total carbon; TN is total nitrogen; OM is organic matter; RW is recycled wastewater; RP is retention pond. Mean values in a column within a golf course with the same letter are not statistically different (Fisher's LSD, $\alpha=0.05$ ).

parameters reported include $\mathrm{EC}, \mathrm{pH}, \mathrm{SAR}, \mathrm{Na}, \mathrm{Mg}, \mathrm{K}, \mathrm{Ca}$, $\mathrm{HCO}_{3}^{-}, \mathrm{S}$ in $\mathrm{SO}_{4}^{-2}, \mathrm{Cl}^{-}$, and total alkalinity.

\subsection{Statistical analyses}

All statistical analyses were performed using the Statistical Analysis Software (SAS 9.3, SAS Institute, Cary, NC, USA). Differences among means were examined using PROC GLM and mean comparison was conducted using Fisher's least significance difference at $\alpha$ level of 0.05 . Single and multiple linear regression analyses using the stepwise technique were performed using the PROC REG procedure to establish the relationships among the soil parameters examined.

\section{Results and discussions}

\subsection{Soil pH, $\mathrm{CaCO}_{3}$, and $\mathrm{OM}$}

Soil $\mathrm{pH}, \% \mathrm{CaCO}_{3}$, and $\% \mathrm{OM}$ between the managed and nonmanaged areas of each golf course facility are summarized in Table 1. Salinity parameters will be discussed separately (see Sect. 3.2). The results indicated little differences in mean $\mathrm{pH}$ between managed and non-managed areas of all the courses examined (Table 1). The differences in means between managed and non-managed areas at each facility ranged between 0.1 and $0.3 \mathrm{pH}$ units and there was no consistent trend observed between the areas. However, these differences were significant $(p<0.05)$ in three $(\mathrm{B}, \mathrm{C}$, and F) of the seven facilities. Percent $\mathrm{CaCO}_{3}$ showed no definite trend with depth and no consistent differences between managed and non- managed areas (Table 1). Although not significantly different, $\% \mathrm{CaCO}_{3}$ was higher in the non-managed zones of four (D, E, F, and G) of the seven courses examined. Organic matter tended to be higher in the managed areas as was observed in six (A, B, C, D, F, and G) of the seven sites, although these were not statistically significant (Table 1). The higher values observed in the managed zones could be attributed to more biomass (Havlin et al., 2005) resulting from better management. The exact same trend observed for soil OM was also reflected in the soil TC and TN, which could be influenced by $\mathrm{N}$ fertilizer additions and $\mathrm{N}$ in irrigation water. Apart from OM, TC, and TN, there was no consistent trend between managed and non-managed areas at the examined set of facilities. The lack of significant differences between managed and non-managed zones for most of the examined soil properties reported here somewhat indicates there are no major external sources of these introduced through irrigation or other management activities.

\subsection{Extractable ions and salinity parameters}

The differences in selected extractable ions and some salinity indicators between managed and non-managed sites at each golf course are summarized in Table 2. Among the extractable cations $(\mathrm{Ca}, \mathrm{K}, \mathrm{Mg}$, and $\mathrm{Na}), \mathrm{Na}$ was significantly higher $(p<0.05)$ in the managed zone of each facility. This finding could somewhat be attributed to the Na contained in the irrigation water originating mainly from groundwater sources (see Sect. 3.3), because $\mathrm{Na}$ is not typically 
Table 2. A summary of extractable ions and soil salinity parameters for the managed and non-managed areas of the seven golf facilities studied in Lubbock, Texas, USA $(n=3)$.

\begin{tabular}{|c|c|c|c|c|c|c|c|c|c|c|c|}
\hline \multirow[b]{2}{*}{$\begin{array}{l}\text { Golf } \\
\text { course }\end{array}$} & \multirow[b]{2}{*}{ Management } & \multirow[b]{2}{*}{$\begin{array}{l}\text { Irrigation } \\
\text { source }\end{array}$} & \multicolumn{4}{|c|}{$\mathrm{NH}_{4}$-acetate-extractable } & \multicolumn{2}{|c|}{ Water-extractable } & \multirow[b]{2}{*}{$\begin{array}{c}\mathrm{EC} \\
\mathrm{dS} \mathrm{m} \mathrm{m}^{-1}\end{array}$} & \multirow[b]{2}{*}{$\begin{array}{c}\text { ESP } \\
\%\end{array}$} & \multirow[b]{2}{*}{ SAR } \\
\hline & & & \multicolumn{4}{|c|}{$\mathrm{mg} \mathrm{kg}^{-1}$} & \multicolumn{2}{|c|}{$\mathrm{mg} \mathrm{kg}^{-1}$} & & & \\
\hline \multirow[t]{2}{*}{ A } & Managed & Well & $271 \mathrm{a}$ & $2165 \mathrm{a}$ & $810 \mathrm{a}$ & $534 \mathrm{a}$ & $253 a$ & 5.9 & $0.445 \mathrm{a}$ & $5.8 \mathrm{a}$ & $5.0 \mathrm{a}$ \\
\hline & Non-managed & & $42.0 \mathrm{~b}$ & $2259 a$ & $160 \mathrm{~b}$ & $321 b$ & $90.3 b$ & nd & $0.199 b$ & $1.3 \mathrm{~b}$ & $1.8 \mathrm{~b}$ \\
\hline \multirow[t]{2}{*}{ B } & Managed & Well & $322 a$ & $2757 b$ & $1058 \mathrm{a}$ & $633 a$ & $170 \mathrm{a}$ & 307.7 & $1.561 \mathrm{a}$ & $5.4 \mathrm{a}$ & $4.7 \mathrm{a}$ \\
\hline & Non-managed & & $47 b$ & $3684 a$ & $569 b$ & $386 b$ & $125 \mathrm{a}$ & nd & $0.417 \mathrm{~b}$ & $0.8 b$ & $1.4 \mathrm{~b}$ \\
\hline \multirow[t]{2}{*}{$\mathrm{C}$} & Managed & Well & $309 a$ & $2355 a$ & $1109 a$ & $600 \mathrm{a}$ & $186 a$ & 236.7 & $1.187 \mathrm{a}$ & $5.7 \mathrm{a}$ & $5.1 \mathrm{a}$ \\
\hline & Non-managed & & $68 b$ & $2786 a$ & $806 b$ & $520 \mathrm{a}$ & $125 \mathrm{a}$ & nd & $0.219 b$ & $1.3 b$ & $1.8 \mathrm{~b}$ \\
\hline \multirow[t]{2}{*}{$\mathrm{D}$} & Managed & Well & $132 \mathrm{a}$ & $1610 \mathrm{~b}$ & $657 \mathrm{a}$ & $380 \mathrm{a}$ & $160 \mathrm{a}$ & 88.8 & $0.426 \mathrm{a}$ & $3.9 \mathrm{a}$ & $3.6 \mathrm{a}$ \\
\hline & Non-managed & & $65.2 \mathrm{~b}$ & $2328 \mathrm{a}$ & $293 b$ & $253 a$ & $125 \mathrm{a}$ & nd & $0.221 b$ & $1.9 \mathrm{~b}$ & $2.2 \mathrm{~b}$ \\
\hline \multirow[t]{2}{*}{$\mathrm{E}$} & Managed & Well & $264 a$ & $2732 b$ & $826 a$ & $441 b$ & $192 a$ & $88.8 \mathrm{a}$ & $0.815 a$ & $5.1 \mathrm{a}$ & $4.5 \mathrm{a}$ \\
\hline & Non-managed & & $107 \mathrm{~b}$ & $5134 \mathrm{a}$ & $912 \mathrm{a}$ & $888 \mathrm{a}$ & $176 a$ & $71.0 \mathrm{a}$ & $0.699 \mathrm{a}$ & $1.3 \mathrm{~b}$ & $1.7 \mathrm{~b}$ \\
\hline \multirow[t]{2}{*}{$\mathrm{F}$} & Managed & Well \& RW & $255 \mathrm{a}$ & $2428 \mathrm{a}$ & $776 a$ & $381 b$ & $189 \mathrm{a}$ & $166 a$ & $0.991 \mathrm{a}$ & $5.4 \mathrm{a}$ & $4.7 \mathrm{a}$ \\
\hline & Non-managed & & $114 \mathrm{~b}$ & $3038 \mathrm{a}$ & $667 a$ & $786 a$ & $214 a$ & $76.9 b$ & $0.605 \mathrm{a}$ & $2.1 \mathrm{~b}$ & $2.3 b$ \\
\hline \multirow[t]{2}{*}{$\mathrm{G}$} & Managed & Well \& RP & $270 a$ & $4401 \mathrm{a}$ & $1140 \mathrm{a}$ & $1272 \mathrm{a}$ & $230 a$ & 59.2 & $0.810 \mathrm{a}$ & $3.3 \mathrm{a}$ & $3.2 \mathrm{a}$ \\
\hline & Non-managed & & $78 b$ & $3872 a$ & $551 \mathrm{~b}$ & $822 b$ & $144 a$ & nd & $0.409 b$ & $1.3 \mathrm{~b}$ & $1.7 \mathrm{~b}$ \\
\hline
\end{tabular}

EC is electrical conductivity; ESP is exchangeable sodium percentage; RW is recycled wastewater; RP is retention pond; SAR is sodium adsorption ratio (estimated using calculated exchangeable sodium ratio); nd is not detected. Mean values in a column within a golf course with the same letter are not statistically different (Fisher's LSD, $\alpha=0.05)$.

added through fertilization. Exchangeable Ca was higher in the non-managed zones of six (A to F) of the seven facilities, and this finding was significant $(p<0.05)$ at three of the facilities. This observed difference could be attributed to the possible leaching of $\mathrm{Ca}$ (possibly in the form of sulfates and chlorides) from the more frequently irrigated areas. Extractable $\mathrm{Mg}$ and $\mathrm{K}$ were found to be higher in the irrigated areas of six of the seven and five of the seven examined facilities, respectively, with significant differences $(p<0.05)$ observed in some facilities (Table 2). The higher levels of these elements in the managed areas are likely due to their addition to the soil from irrigation water (see Sect. 3.3) because they are not typically added through fertilization in this region. In general, the chloride salts of $\mathrm{Ca}$ are more soluble than those of $\mathrm{Mg}$ and $\mathrm{K}$, while the sulfate salts of $\mathrm{Mg}$ and $\mathrm{K}$ are more soluble than those of $\mathrm{Ca}$, and carbonate salts are generally insoluble (Clugston and Flemming, 2000). Thus, using their solubility characteristics, it could be inferred that $\mathrm{Na}, \mathrm{Mg}$, and $\mathrm{K}$ in these soils could be more of carbonate salts because they will be less soluble and thus mildly leached by irrigation water. Conversely, $\mathrm{Ca}$, which tended to be more susceptible to leaching from these irrigated zones, could be predominantly in the form of chloride salts of $\mathrm{Ca}$. The slight positive relationship $\left(R^{2}=0.65, p<0.05\right)$ observed between $\mathrm{Na}$ and $\mathrm{Cl}^{-}$could suggest the presence of chloride salts of $\mathrm{Na}$ as well.
The water-extractable anions examined revealed that $\mathrm{HCO}_{3}^{-}$and $\mathrm{Cl}^{-}$were mostly higher in the managed areas compared to the non-managed areas, some of which were significantly different (Table 2). The only exception was $\mathrm{HCO}_{3}^{-}$in facility $\mathrm{F}$. The higher levels of these anions in the managed zones of these facilities could be attributed to their addition to the soil from irrigation water sources. The dominant anions in the soil solution of most semi-arid salty soils are $\mathrm{Cl}^{-}, \mathrm{SO}_{4}^{-2}, \mathrm{HCO}_{3}^{-}$(at $\mathrm{pH}$ values of 6.0-8.0), and some $\mathrm{NO}_{3}^{-}$(Dierickx, 2013). Thus, significant increases in these ions could reflect a shift toward soil salinization. In this study, less emphasis was placed on soil $\mathrm{SO}_{4}^{-2}, \mathrm{NO}_{3}^{-}$, and $\mathrm{PO}_{4}^{-3}$ concentrations because these are commonly added through fertilization, and thus possible contribution from irrigation sources would not be easily quantified.

The potential contribution of the management practices to salinity and sodicity could be evidenced from the examination of the soil EC, ESP, and SAR values. It is apparent that the practices at the facilities and possibly irrigation water tended to increase the salinity and sodicity properties of these soils. This is supported by the significantly higher EC, ESP, and SAR values generally observed in the managed areas of these facilities (Table 2). A comparison was made among depths to examine the distribution of EC, ESP, and SAR between all managed and non-managed sites (Fig. 2). When all the managed zones were grouped and compared against the non-managed zone, at each depth, the salinity parameters 


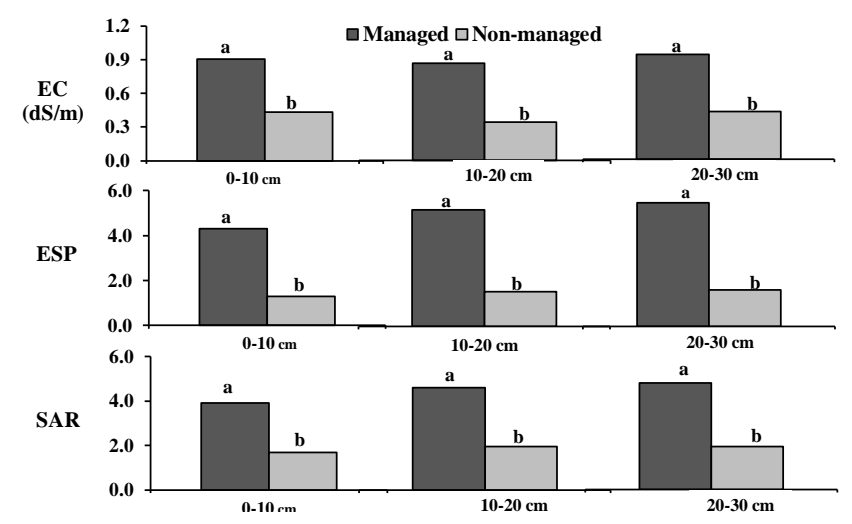

Figure 2. Differences in selected soil chemical properties examined within depths between managed and non-managed zones of all seven golf courses examined in Lubbock, Texas, USA $(n=7)$. Mean values within a soil depth with the same letter are not statistically different (Fisher's LSD, $\alpha=0.05$ ). EC is electrical conductivity; ESP is exchangeable sodium percentage; SAR is sodium adsorption ratio.

were significantly higher in the managed zones, suggesting the effects were similar within all the depths examined. Besides irrigation, this shift toward salinization is further supported by the semi-arid condition of the study site, characterized by low rainfall and less leaching of the soluble salts, leading to their buildup in the top soil.

\subsection{Influence of local aquifer water quality}

The water quality reports obtained from the facilities are summarized in Table 3. Interestingly, the concentration of each parameter examined (with the exception of $\mathrm{pH}$ ) was on the average approximately 2 times higher in the well water compared to the retention pond, which is mainly a collection of runoff and rainwater (Table 3). These differences could be most likely attributed to the inherently low pollutant concentration in rainwater, filtration of pollutants as it flows over vegetation on its way to the pond, and further settling of pollutants and uptake by vegetation in the reservoir. The concentrations of the examined parameters in the effluent treated water were 2-11 times higher than those of the well water. Using the water quality information, pollutant addition to soil from the water sources could be estimated. For instance, using the average values of contaminants in the well water, approximately $5.60 \mathrm{~g} \mathrm{Cl}^{-}, 7.60 \mathrm{~g} \mathrm{SO}_{4}^{-2}, 9.0 \mathrm{~g} \mathrm{HCO}_{3}^{-}$, and $3.80 \mathrm{~g} \mathrm{Na}^{+}$will be added to $1.0 \mathrm{~kg}$ of the receiving soil over a 10-year period if a field receives approximately $1200 \mathrm{~mm} \mathrm{yr}^{-1}$ of irrigation water from well sources in this area. The limited rainfall and thus minimal leaching of salts in the semi-arid and arid areas could make the situation described above more realistic.

The well water quality, which is a better representation of that of the local aquifer, was further examined. The available data were grouped into three sets - 1991-1993, 2004-2008,
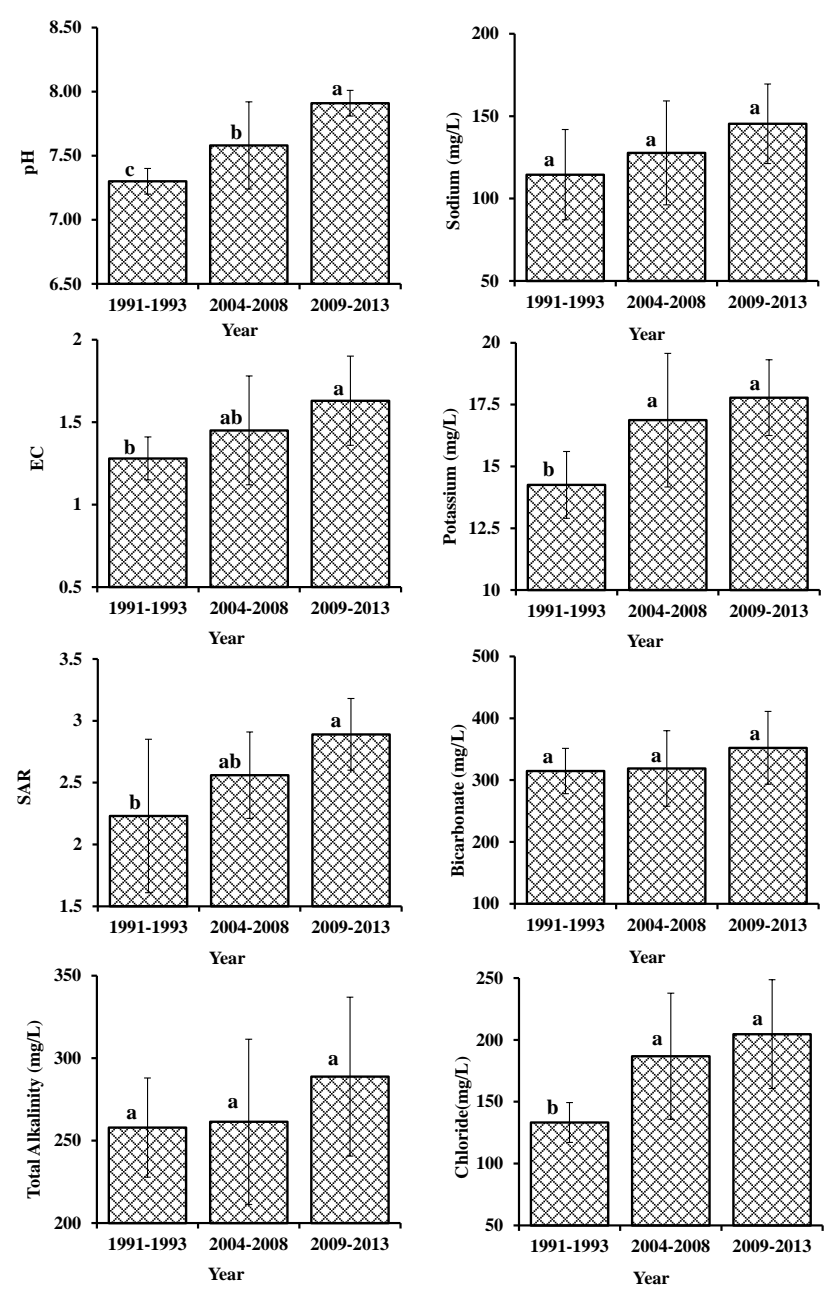

Figure 3. The observed trend in selected water quality parameters from 1991 to 2013. Water samples were obtained from well sources utilized by a golf course in Lubbock, Texas, USA. For each parameter, data were averaged over 1991-1993 $(n=9), 2004-2008$ $(n=6)$, and 2009-2013 $(n=6)$; error bars are for the standard deviations. Mean values within a parameter with the same letter are not statistically different (Fisher's LSD, $\alpha=0.05$ ).

and 2009-2013 - and the average values for each parameter in a set were calculated. A striking feature observed was the gradual increase in $\mathrm{pH}, \mathrm{EC}, \mathrm{SAR}$, total alkalinity, $\mathrm{Na}$, $\mathrm{K}, \mathrm{HCO}_{3}^{-}$, and $\mathrm{Cl}^{-}$over the years (Fig. 3), suggesting that the declining aquifer (Terrel and Johnson, 1999; Terrel et al., 2002) could be associated with an increase in contaminant concentration, particularly salts. Using the mean values, the $\mathrm{Na}^{+}: \mathrm{Ca}^{+2}$ ratio of approximately $2: 1$ in the well water sources likely explains the higher SAR and ESP in the managed areas that are irrigated using water from well sources. This ratio is higher than those of recycled wastewater $(1.5: 1)$ and ditch water (1:1) reported by Qian and Mecham (2005) that still led to higher SAR in soils after years of irrigation in Denver and Fort Collins, Colorado. Thus, our findings sug- 
Table 3. Typical concentrations ranges (mean) of selected water quality indicators from well, retention pond, and recycled wastewater sources summarized from four different golf courses in the city of Lubbock, Texas, USA, from 1991 to 2013 (number of years = 15, 4, and 1 for well, retention pond, and recycled wastewater sources, respectively).

\begin{tabular}{lllc}
\hline Parameters & Well & Retention pond & Recycled water \\
\hline SAR & $2.09-3.18(2.70)$ & $1.42-1.76(1.92)$ & 7.87 \\
$\mathrm{EC}\left(\mathrm{dS} \mathrm{m}^{-1}\right)$ & $0.89-2.38(1.58)$ & $0.49-1.27(0.74)$ & 8.26 \\
$\mathrm{pH}$ & $7.03-8.23(7.78)$ & $7.73-8.67(8.22)$ & 6.41 \\
Chloride $\left(\mathrm{mg} \mathrm{L}^{-1}\right)$ & $101-338(205)$ & $31.2-110(57.2)$ & 2400 \\
Sulfate $\left(\mathrm{mg} \mathrm{L}^{-1}\right)$ & $140.8-447(277)$ & $55.7-196(98.5)$ & 1329 \\
Bicarbonate $\left(\mathrm{mg} \mathrm{L}^{-1}\right)$ & $251-426(330)$ & $178-383(230)$ & 615 \\
Carbonate $\left(\mathrm{mg} \mathrm{L}^{-1}\right)$ & $16.8(16.8)$ & - & - \\
Potassium $\left(\mathrm{mg} \mathrm{L}^{-1}\right)$ & $13.8-21.9(17.3)$ & $8.60-14.5(10.2)$ & 47.3 \\
Sodium $\left(\mathrm{m} \mathrm{L}^{-1}\right)$ & $79.3-188(139)$ & $40.5-126(68.6)$ & 792 \\
Calcium $\left(\mathrm{mg} \mathrm{L}^{-1}\right)$ & $42.5-111(77.0)$ & $25.3-43.3(33.0)$ & 332 \\
Magnesium $\left(\mathrm{mg} \mathrm{L}^{-1}\right)$ & $37.3-134.3(75.3)$ & $18.7-71.5(35.5)$ & 264 \\
\hline
\end{tabular}

gest that continuous irrigation with well water could increase the salt contents of the receiving soils overtime, a situation that is already apparent in the managed zones of the facilities examined in this study as discussed under Sect. 3.2. The water quality data and the observed differences in salinity parameters between managed (irrigated) and non-managed (non-irrigated) areas establish a possible influence of the aquifer water quality on soil quality at these facilities.

\subsection{Application of PXRF to salinity prediction}

The PXRF-quantified $\mathrm{Ca}, \mathrm{Cl}, \mathrm{K}$, and $\mathrm{S}$ were individually and collectively used to explain the variability associated with salinity, approximated using EC. The findings are presented in Table 4. As evidenced from the $R^{2}$ values, when all the sites were considered, approximately $70 \%$ of the variability associated with salinity was explained by the $\mathrm{Cl}$ alone, $82 \%$ by $\mathrm{Cl}$ and $\mathrm{S}$, and $85 \%$ by $\mathrm{Cl}, \mathrm{S}$, and $\mathrm{K}$. The findings here suggest the likely contributions of salts of $\mathrm{Cl}^{-}$and $\mathrm{SO}_{4}^{-2}$ to soil salinity within these facilities. When studied individually, the strengths of these relationships were notably higher within the managed area compared to the non-managed area (Table 4) as evidenced from $R^{2}$ average of 0.72 (managed) vs. 0.29 (non-managed) for all the relationships examined. The stronger relationships observed within the managed group support part of our hypothesis that salinity (EC) is influenced by anthropogenic sources; thus, the more the input of these cation and anion-forming elements through irrigation, fertilization, etc., the higher the salinity. The weaker relationships observed within the non-managed group suggest a limited influence of the anthropogenic sources of the elements (particularly $\mathrm{Cl}$ and $\mathrm{S}$ ), further suggesting that salinity could be controlled by other parameters that were not accounted for by the PXRF. From this information, it can be inferred that the chemistry of salinity, i.e., the elemental species contributing to it, could be different within the managed and the non-managed groups. This is an important piece of informa- tion that was rapidly obtained using the PXRF. Overall, the relationships developed when all data points (managed and non-managed) were collectively considered suggest that the PXRF could be used for rapid prediction and examination of chemistry of salinity in the semi-arid urban soils, an application that could be extended to other semi-arid regions. However, it is important to note that the capability of this tool is still limited since the contributions of some elements such as $\mathrm{Na}$ and anions such as $\mathrm{HCO}_{3}^{-}$and $\mathrm{CO}_{3}^{-2}$ cannot be ascertained yet.

\section{Conclusions}

The impacts of management practices on environmental quality could vary with climate and thus site-specific investigations are often desired, because extending findings from one practice and location to others could be misleading. Thus, this study serves as an initial probe into the potential management-induced changes in soil chemical properties with a focus on salinity in golf courses in Lubbock, Texas, located in the SHP of the USA. This is an area characterized by semi-arid climatic conditions, typified by drought, wind erosion, and potential for soil salinization. Evaluation of soil chemical properties of managed (irrigated) and non-managed (non-irrigated) areas at seven different golf course facilities and information on well water quality revealed possible differences in soil properties. The major findings are summarized as follows: (1) among the exchangeable cations, $\mathrm{Na}$ was significantly higher in all the managed and well-irrigated zones of all the seven golf courses, suggesting the addition of $\mathrm{Na}$ salts (possibly in the forms of carbonates and chlorides) to irrigated soils from irrigation water sources. (2) Irrigation tended to increase the salinity and sodicity properties of the soils as evidenced from the significantly higher Soil EC, ESP, and SAR observed in majority of the managed areas compared to the non-managed areas. This finding was supported by the water quality data of the local aquifer, which showed 
Table 4. Regression equation and coefficient of determination for the relationships between electrical conductivity (EC) and the selected PXRF-quantified elements within managed and non-managed facilities of the golf courses in Lubbock, Texas, USA ( $n=42)$.

\begin{tabular}{|c|c|c|}
\hline & All facilities $(n=42)$ & \\
\hline Parameter (s) & Equation & $R^{2}$ \\
\hline $\mathrm{Cl}$ & $\mathrm{EC}=0.0015 \mathrm{Cl}+0.2476$ & $0.70^{\mathrm{c}}$ \\
\hline S & $\mathrm{EC}=0.0007 \mathrm{~S}-0.5716$ & $0.63^{\mathrm{c}}$ \\
\hline $\mathrm{Ca}$ & $\mathrm{EC}=0.00001 \mathrm{Ca}+0.3813$ & 0.23 \\
\hline $\mathrm{K}$ & $\mathrm{EC}=0.0341 \mathrm{~K}+160.28$ & 0.06 \\
\hline $\mathrm{Cl}+\mathrm{S}$ & $\mathrm{EC}=0.001 \mathrm{Cl}+0.0004 \mathrm{~S}-0.3063$ & $0.82^{\mathrm{c}}$ \\
\hline $\mathrm{Cl}+\mathrm{K}$ & $\mathrm{EC}=0.0015 \mathrm{Cl}+0.00004 \mathrm{~K}-0.2876$ & $0.77^{\mathrm{c}}$ \\
\hline $\mathrm{Cl}+\mathrm{Ca}$ & $\mathrm{EC}=0.0014 \mathrm{Cl}+0.000006 \mathrm{Ca}+0.1490$ & $0.75^{\mathrm{c}}$ \\
\hline $\mathrm{Cl}+\mathrm{S}+\mathrm{K}$ & $\mathrm{EC}=0.0012 \mathrm{Cl}+0.00003 \mathrm{~S}+0.00003 \mathrm{~K}+-0.5931$ & $0.85^{\mathrm{c}}$ \\
\hline $\mathrm{Cl}+\mathrm{S}+\mathrm{Ca}$ & $\mathrm{EC}=0.0010 \mathrm{Cl}+0.0004 \mathrm{~S}+0.000003 \mathrm{Ca}-0.3004$ & $0.83^{\mathrm{c}}$ \\
\hline \multirow[t]{2}{*}{$\mathrm{Cl}+\mathrm{Ca}+\mathrm{K}$} & $\mathrm{EC}=0.0014 \mathrm{Cl}+0.000003 \mathrm{Ca}+0.00003 \mathrm{~K}-0.2085$ & $0.78^{\mathrm{c}}$ \\
\hline & Managed $(n=21)$ & \\
\hline Parameter (s) & Equation & $R^{2}$ \\
\hline $\mathrm{Cl}$ & $\mathrm{EC}=0.0017 \mathrm{Cl}+0.1987$ & $0.85^{\mathrm{c}}$ \\
\hline $\mathrm{S}$ & $\mathrm{EC}=0.0007 \mathrm{~S}-0.4108$ & $0.52^{b}$ \\
\hline $\mathrm{Ca}$ & $\mathrm{EC}=0.00002 \mathrm{Ca}+0.5547$ & $0.43^{\mathrm{b}}$ \\
\hline $\mathrm{K}$ & $\mathrm{EC}=0.0444 \mathrm{~K}+275.83$ & 0.09 \\
\hline $\mathrm{Cl}+\mathrm{S}$ & $\mathrm{EC}=0.0014 \mathrm{Cl}+0.0002 \mathrm{~S}-0.1399$ & $0.89^{\mathrm{c}}$ \\
\hline $\mathrm{Cl}+\mathrm{K}$ & $\mathrm{EC}=0.0017 \mathrm{Cl}+0.1987 \mathrm{~K}-0.1459$ & $0.88^{\mathrm{c}}$ \\
\hline $\mathrm{Cl}+\mathrm{Ca}$ & $\mathrm{EC}=0.0015 \mathrm{Cl}+0.000005 \mathrm{Ca}+0.1796$ & $0.87^{\mathrm{c}}$ \\
\hline $\mathrm{Cl}+\mathrm{S}+\mathrm{K}$ & $\mathrm{EC}=0.0014 \mathrm{Cl}+0.0002 \mathrm{~S}+0.00002 \mathrm{~K}-0.4151$ & $0.91^{\mathrm{c}}$ \\
\hline $\mathrm{Cl}+\mathrm{S}+\mathrm{Ca}$ & $\mathrm{EC}=0.0013 \mathrm{Cl}+0.0002 \mathrm{~S}+0.000004 \mathrm{Ca}-0.1250$ & $0.91^{\mathrm{c}}$ \\
\hline \multirow[t]{2}{*}{$\mathrm{Cl}+\mathrm{Ca}+\mathrm{K}$} & $\mathrm{EC}=0.0015 \mathrm{Cl}+0.0000003 \mathrm{Ca}+0.00002 \mathrm{~K}-0.0718$ & $0.89^{\mathrm{c}}$ \\
\hline & Non-managed $(n=21)$ & \\
\hline Parameter (s) & Equation & $R^{2}$ \\
\hline $\mathrm{Cl}$ & $\mathrm{EC}=0.0003 \mathrm{Cl}+0.3598$ & 0.03 \\
\hline $\mathrm{S}$ & $\mathrm{EC}=0.0005 \mathrm{~S}-0.3238$ & $0.39^{\mathrm{b}}$ \\
\hline $\mathrm{Ca}$ & $\mathrm{EC}=0.000005 \mathrm{Ca}+0.2884$ & 0.10 \\
\hline $\mathrm{K}$ & $\mathrm{EC}=0.0392 \mathrm{~K}-171.05$ & 0.26 \\
\hline $\mathrm{Cl}+\mathrm{S}$ & $\mathrm{EC}=0.00035 \mathrm{Cl}+0.000516 \mathrm{~S}-0.3803$ & $0.43^{\mathrm{b}}$ \\
\hline $\mathrm{Cl}+\mathrm{K}$ & $\mathrm{EC}=0.0004 \mathrm{Cl}+0.000004 \mathrm{~K}-0.2820$ & $0.33^{\mathrm{a}}$ \\
\hline $\mathrm{Cl}+\mathrm{Ca}$ & $\mathrm{EC}=0.00037 \mathrm{Cl}+0.000006 \mathrm{Ca}+0.2321$ & 0.15 \\
\hline $\mathrm{Cl}+\mathrm{S}+\mathrm{K}$ & $\mathrm{EC}=0.00042 \mathrm{Cl}+0.0004 \mathrm{~S}+0.00002 \mathrm{~K}-0.5226$ & $0.49^{b}$ \\
\hline $\mathrm{Cl}+\mathrm{S}+\mathrm{Ca}$ & $\mathrm{EC}=0.0003 \mathrm{Cl}+0.0005 \mathrm{~S}-0.00000007 \mathrm{Ca}-0.3946$ & $0.43^{\mathrm{b}}$ \\
\hline $\mathrm{Cl}+\mathrm{Ca}+\mathrm{K}$ & $\mathrm{EC}=0.0005 \mathrm{Cl}+0.000000008 \mathrm{Ca}+0.00004 \mathrm{~K}-0.2804$ & 0.33 \\
\hline
\end{tabular}

${ }^{\text {a }}$ Significant at 0.05 probability level; ${ }^{\text {b }}$ Significant at 0.01 probability level;

${ }^{\mathrm{c}}$ Significant at 0.001 probability level; $\mathrm{EC}$ in $\mathrm{dS} \mathrm{m}^{-1} ; \mathrm{Cl}, \mathrm{S}, \mathrm{Ca}$, and $\mathrm{K}$ in $\mathrm{mg} \mathrm{kg}^{-1}$.

an increase in $\mathrm{pH}, \mathrm{EC}, \mathrm{SAR}$, total alkalinity, and extractable ions over the years. (3) PXRF-quantified $\mathrm{Cl}$ and $\mathrm{S}$, and to a lesser extent $\mathrm{Ca}$, individually and collectively explained most of the variability associated with salinity within the soils of these facilities. The strengths of the relationships were generally higher in the managed area.

Although in the SHP and other semi-arid and arid regions the emphasis is more on water quantity, it is important to point out that salt buildup can affect water quality by altering the hydrological properties of soils such as hydraulic conductivity, infiltration, permeability, water holding capacity, and thus water availability to crops. This study was an initial investigation into an observed environmental issue and findings will support future research effort in the subject area. 
Author contributions. J. Young and T. K. Udeigwe planned and implemented the study. T. Kandakji and P. Gautam assisted in field and laboratory activities. M. A. Mahmoud suggested ideas and assisted in various aspects of the project as needed. D. C. Weindorf provided assistance with the portable X-ray fluorescence spectrometer.

Acknowledgements. We thank the golf course superintendents at the local courses who allowed us to collect soil samples from their courses to complete this work.

Edited by: P. Pereira

\section{References}

Aldabaa, A. A. A., Weindorf, D. C., Chakraborty, S., Sharma, A., and $\mathrm{Li}, \mathrm{B} .:$ Combination of proximal and remote sensing methods for rapid soil salinity quantification, Geoderma, 239-240, 34-46, 2015.

Clugston, M. and Flemming, R.: Advanced Chemistry, Oxford University Press, Oxford, UK, 2000

Dierickx, W.: The salinity and alkalinity status of arid and semiarid lands, Land Use, Land Cover and Soil Sciences, 5, 163-189, 2013.

Du Laing, G., Rinklebe, J., Vandecasteele, B., Meers, E., and Tack, F. M. G.: Trace metal behaviour in estuarine and riverine floodplain soils and sediments: a review, Sci. Total Environ., 407, 3972-3985, 2009.

Fan, X., Pedroli, B., Liu, G., Liu, Q., Liu, H., and Shu, L.: Soil salinity development in the yellow river delta in relation to groundwater dynamics, Land Degrad. Dev., 23, 175-189, 2012.

Gardner, D., Weindorf, D. C., and Flynn, M.: Presence of chromium, copper, and arsenic in schoolyard soils, Soil Horizons, 54, 1-5, doi:10.2136/sh12-12-0032, 2013.

Havlin, J. L., Beaton. J. D., Tisdale, S. L., and Nelson, W. L.: Soil fertility and fertilizers: an introduction to nutrient management, Vol. 515, Pearson Prentice Hall, Upper Saddle River, NJ, USA, 2005.

Herrero, J. and Pérez-Coveta, O.: Soil salinity changes over 24 years in a Mediterranean irrigated district, Geoderma, 125, 287-308, 2005.

Hu, W., Huang. B., Weindorf, D. C., and Chen, Y.: Metals analysis of agricultural soils via portable X-ray fluorescence spectrometry, B. Environ. Contam. Tox., 92, 420-426, 2014.

Hudak, P. F.: Distribution and sources of arsenic in the southern high plains aquifer, TX, USA, J. Environ. Sci. Heal. A, 35, 899-913, 2000.

Jang, M.: Application of portable X-ray fluorescence (pXRF) for heavy metal analysis of soils in crop fields near abandoned mine sites, Environ. Geochem. Hlth., 32, 207-216, 2010.

Kalnicky, D. J. and Singhvi, R.: Field portable XRF analysis of environmental samples, J. Hazard. Mater., 83, 93-122, 2001

Kilbride, C., Poole, J. and Hutchings, T. R.: A comparison of $\mathrm{Cu}, \mathrm{Pb}, \mathrm{As}, \mathrm{Cd}, \mathrm{Zn}, \mathrm{Fe}, \mathrm{Ni}$ and $\mathrm{Mn}$ determined by acid extraction/ICP-OES and ex situ field portable X-ray fluorescence analyses, Environ. Pollut, 143, 16-23, 2006.
Loeppert, R. H. and Suarez, D. L.: Carbonate and gypsum, in: Methods of Soil Analysis, Part 3, Chemical Methods, edited by: Bartels, J. M. and Bigham, J. M., Soil Science Society of America, Inc., Madison, USA, SSSA Book Series 5, 437-474, 1996.

Martinez-Beltran, J. and Manzur, C. L.: Overview of salinity problems in the world and FAO strategies to address the problem, in: Proceedings of the international salinity forum, Riverside, CA, USA, 311-313, 2005.

McWhirt, A., Weindorf, D. C., and Zhu, Y.: Rapid analysis of elemental concentrations in compost via portable X-ray fluorescence spectrometry, Compost Sci. Util., 20, 185-193, 2012.

Morgan, R. P. C.: Soil Erosion and Conservation, Blackwell Publishing, Oxford, UK, 2009.

Nelson, D. W. and Sommers, L. E.: Total carbon, organic carbon, and organic matter, in: Methods of Soil Analysis, Part 3, Chemical Methods, edited by: Sparks D. L., Soil Science Society of America Book Ser. 5, SSSA and ASA, Madison, WI, USA, 9611010, 1996.

NOAA: NOAA Online Weather Data (Lubbock Area), available at: http://www.weather.gov/climate/xmacis.php?wfo=lub, last access: 30 March 2015.

Nordstrom, K. F. and Hotta, S.: Wind erosion from cropland in the USA: a review of problems, solutions and prospects, Geoderma, 121, 157-167, 2004.

Pariente, S.: Soluble salts dynamics in the soil under different climatic conditions, Catena, 43, 307-321, 2001.

Peel, M. C., Finlayson, B. L., and McMahon, T. A.: Updated world map of the Köppen-Geiger climate classification, Hydrol. Earth Syst. Sci., 11, 1633-1644, doi:10.5194/hess-11-16332007, 2007.

Pitman, M. G. and Läuchli, A.: Global impact of salinity and agricultural ecosystems, in: Salinity: EnvironmentPlants-Molecules, Springer, the Netherlands, Part A, 3-20, doi:10.1007/0-306-48155-3_1, 2002.

Qian, Y. L. and Mecham, B.: Long-term effects of recycled wastewater irrigation on soil chemical properties on golf course fairways, Agron. J., 97, 717-721, 2005.

Rengasamy, P.: World salinization with emphasis on Australia, J. Exp. Bot., 57, 1017-1023, 2006.

Rhoades, J. D.: Salinity: electrical conductivity and total dissolved solids, in: Methods of Soil Analysis, III, Chemical Methods, edited by: Sparks, D. L., SSSA, Madison, WI, USA, 417-435, 1996.

Richards, L. A.: Diagnosis and Improvement of Saline and Sodic Soils, USDA Agric. Handb. 60, USDA, Washington, DC, USA, 1954.

Scanlon, B. R., Nicot, J. P., Reedy, R. C., Tachovsky, J. A., Nance, S. H., Smyth, R. C., Keese, K., Ashburn, R. E., and Christian, L.: Evaluation of arsenic contamination in Texas, The Univ. of Texas at Austin, Bureau of Economic Geology, final report prepared for Texas Commission on Environmental Quality, under umbrella contract no. 582-4-56385 and work order no. UT-08-570828, 177, 167 pp., 2005.

Snowden, C., Ritchie, G., Cave, J., Keeling, W., and Rajan, N.: Multiple irrigation levels affect boll distribution, yield, and fiber micronaire in cotton, Agron. J., 105, 1536-1544, 2013.

Soil Survey Staff: Chemical analyses, calcium carbonate (4E) $\mathrm{HCl}$ treatment (4E1) manometer, electronic (4E1) <20mm basis $(4 \mathrm{E})$, 
in: Soil Survey Laboratory Manual, USDA-NRCS SSRI \#42, Version 4.0, 269-273, 1996.

Soil Survey Staff: Soil Survey Field and Laboratory Methods Manual, Soil Survey Investigations Report No. 51, Version 1.0, edited by: Burt, R., US Department of Agriculture, Natural Resources Conservation Service, 2009.

Sparks, D. L.: Environmental Soil Chemistry, Academic Press, San Diego, CA, USA, 2003.

Swanhart, S., Weindorf, D. C., Chakraborty, S., Bakr, N., Zhu, Y., Nelson, C., Shook, K., and Acree. A.: Measuring soil salinity via portable X-ray fluorescence spectrometry, Soil Sci., 179, 417423, 2015.

Terrell, B. L. and Johnson, P. N.: Economic impact of the depletion of the Ogallala Aquifer: a case study of the southern high plains of Texas, in: American Agricultural Economics Association annual meeting, Nashville, TN, USA, 8-11 August 1999.

Terrell, B. L., Johnson. P. N., and Segarra, E.: Ogallala Aquifer depletion: economic impact on the Texas high plains, Water Policy, 4, 33-46, 2002.

US Environmental Protection Agency: Method 6200: Field Portable X-Ray Fluorescence Spectrometry for the Determination of Elemental Concentrations in Soil and Sediment, USEPA, 2007.
USDA-NASS: Cotton ginning 2013 summary, available at: http://usda.mannlib.cornell.edu/usda/current/CottGinnSu/ CottGinnSu-05-09-2014.pdf (last access: 30 March 2015), 2014.

USGA: How Much Water Does Golf Use and Where Does It Come From?, available at: http://www.usga.org/uploadedFiles/ USGAHome/Course_Care/Golf_and_the_Environment/Water/ 214418\%20Lyman,\%20Greg\%20-\%20How\%20Much\% 20Water\%20Does\%20Golf\%20Use.pdf (last access: 30 March 2015), 2012.

USGS: National Elevation Dataset, available at: http://ned.usgs. gov/, (last access: 30 March 2015), 2014.

Weindorf, D. C., Zhu, Y., Chakraborty, S., Bakr, N., and Huang, B.: Use of portable X-ray fluorescence spectrometry for environmental quality assessment of peri-urban agriculture, Environ. Monit. Assess., 184, 217-227, 2012.

Weindorf, D. C., Herrero, J., Castañeda, C., Bakr, N., and Swanhart, S.: Direct soil gypsum quantification via portable $\mathrm{X}$-ray fluorescence spectrometry, Soil Sci. Soc. Am. J., 77, 2071-2077, 2013.

Weindorf, D. C., Bakr, N., and Zhu, Y.: Advances in portable X-ray fluorescence (PXRF) for environmental, pedological, and agronomic applications, Adv. Agron., 128, 1-45, 2014. 